\title{
TRADISI BERGUBALANDALAM PERKAWINAN MASYARAKAT MUARA ENIM SUMATERA SELATAN MENURUT PERSPEKTIF ISLAM
}

\author{
Ardiun Hindi \\ Fakultas Syari'ah UIN Maliki Malang \\ Telepon:085646494840
}

\begin{abstract}
Abstrak
Bergubalan adalah sebuah tradisi pelamaran gadis yang berlangsung di Desa Pagar Agung, Kecamatan Rambang, Kabupaten Muara Enim Sumatera Selatan. Dalam tradisi tersebut peminang tidak menemui orang tua gadis yang diinginkannya, akan tetapi hanya mengutarakan keinginannya kepada gadis yang disenanginya. Ketika keduanya sepakat menikah, maka mereka bisa bermufakat untuk pulang ke rumah salah satu perangkat desa, seperti Kepala Desa, dengan tujuan agar segera dinikahkan. Penelitian ini dilakukan dengan menggunakan field research (penelitian lapangan) dan pendekatan dekriptif kualitatif. Penelitian ini menggunakan sumber data primer dan sekunder yang dikumpulkan melalui metode observasi, wawancara dan dokumentasi. Data dianaisa dengan mengunakan metode deskritif kualitatif. Hasil penelitian menunjukkan bahwa tradisi Bergubalan dilihat dari berbagai sudut pandang baik dari konsep dasar peminangan (khithbah) dan perkawinan maupun dilihat dari konsep dasar adat ('urf), tidak ditemukan hal-hal yang berkonfrontasi dengan Islam, oleh karenanya bergubalan ditinjau dari hukum Islam adalah boleh (mubah).
\end{abstract}

Bergubalan is a marriage proposal tradition which runs in Pagar Agung village, Rembang sub-district, Muara Enim, North Sumatera. In this Tradition, a man does not propose marriage to the girl's parents or her guardian but he will ask the girl directly. If both of them agree each other to marry, they will come to official village in order they can marry soon. This research is conducted by field research method and qualitative descriptive approach. It also uses primary and secondary source data which are collected by observation methode, interview and documentation. The data are analyzised by qualitative descriptive method.The result shows that Begubalan tradition is not confronting with Islam from marriage proposal ( khitbah)basic concept and custom $u r f$ ) basic concept. Therefore this tradition is allowed in Islam.

Kata Kunci: Tradisi, Pelamaran, Begubalan,

Tujuan perkawinan sebagaimana yang diisyaratkan oleh teks suci dan Undang-undang dapat direalisasikan dengan baik dan sempurna jika perkawinan sejak proses pendahuluannya (muqaddimat al-zawâj) berjalan sesuai dengan ketentuan-ketentuan yang telah digariskan oleh agama. Diantara proses yang akan dilalui adalah peminangan (khitbah). Karena dalam peminangan tersebut antara calon suami dan isteri bertemu, berkenalan,dan saling mengetahui dari segi perbuatan dan sifat-sifatnya, sehingga ketika keduanya telah menikah, diharapkan dapat saling menutupi dan mengerti terhadap kekurangan masing-masing.

Dalam melaksanakan peminangan, Islam tidak memberikan tata cara yang baku, namun dipasrahkan pada adat dan kebiasaan yang berlaku dalam masyarakat. Berangkat dari kelonggaran ini, 
maka dalam tata pelaksanaan khithbah masyarakat mengikuti tatacara adat yang telah lama ada dalam kehidupan mereka, bagaimanapun beranekanya sebuah adat, orang tua atau wali tetap dilibatkan dalam pelaksanaan peminangan tersebut.

Namun asumsi tersebut tidak selamanya benar, sebab di Indonesia bagian barat tepatnya di Desa Pagar Agung, Kecamatan Rambang, Kabupaten Muara Enim, Sumatera Selatan, terdapat tradisi peminangan yang sangat menarik dan unik yang disebut "bergubalan". Di dalam tradisi bergubalan tersebut peminang tidak menemui orang tua atau wali si gadis yang diinginkan, melainkan hanya mengutarakan keinginannya kepada si gadis tersebut. Ketika keduanya saling cocok, maka keduanya membentuk satu kesepakatan untuk pulang ke salah satu perangkat desa, umumnya Kepala Desa karena dinilai lebih menjamin keabsahan tradisi ini dengan tujuan agar segera dinikahkan. Sebelumnya, mereka akan ditanya tentang sejauh mana keputusan keduanya. Jika keputusan telah disepakati dan dianggap baik, maka selanjutnya mereka ditempatkan di rumah yang terpisah. $\mathrm{Pa}-$ da keesokan harinya berita bergubalan tersebut disampaikan oleh pihak tuan rumah yang dijadikan tempat bergubalan, kepada kedua orang tua pihak laki-laki dan perempuan serta masyarakat setempat.

Dalam fenomena bergubalan tersebut, terdapat doktrin bahwa pelaku bergubalan harus dinikahkan terlepas dari setuju tidaknya orang tua kedua pihak, atas nama adat kebiasaan, orang tua kedua belah pihak dituntut untuk menyetujui pernikahan keduannya. Hak ijbar bagi wali $m u$ jbir yang dilegalkan oleh Islam tidak bisa berbuat banyak dalam hal ini. Sekalipun mayoritas masyarakat Desa Pagar Agung mayoritas memeluk agama Islam.

Berangkat dari uraian latar belakang masalah di atas, maka penelitian ini bertujuan untuk menjelaskan latar belakang berlangsungnya tradisi bergubalan dan melihat bagaimana pandangan masyarakat Muara Enim Sumatera Selatan serta pandangan Islam terhadap tradisi tersebut dengan menggunakan konsep peminangan dalam perspektif Islam sebagai alat analisa.

\section{METODE}

Penelitian ini tergolong dalam penelitian kualitatif. Penelitian kualitatif ini merupakan tata cara penelitian yang menghasilkan data deskriptif, yaitu apa yang dinyatakan oleh responden secara tertulis atau lisan dan prilaku nyata. Adapun hal yang diteliti dan dipelajari adalah objek penelitian yang utuh, sepanjang hal tersebut mengenai manusia. Di mana penelitian tersebut, bukan untuk menguji suatu teori tetapi di maksudkan untuk mengetahui latar belakang berlangsungnya tradisi bergubalan dan melihat bagaimana pandangan masyarakat Muara Enim Sumatera Selatan serta pandangan Islam terhadap tradisi tersebut.

Pendekatan penelitian yang digunakan dalam penelitian ini adalah deskriptif kualitatif. Dalam penelitian ini, peneliti akan menggali tentang sifat-sifat, keadaan, ataupun gejala yang dimunculkan oleh masyarakat Muara Enim Sumatera Selatan. Setelah data ditemukan dan telah terkumpul, maka selanjutnya peneliti akan mengambarkannya dalam bentuk uraian.

Dalam penelitian ini, jenis penelitian yang digunakan adalah field research (penelitian lapangan), karena dalam penelitian ini peneliti akan menggambarkan secara detail dan mendalam tentang suatu keadaan atau fenomena dari objek penelitian yang diteliti dengan cara mengembangkan konsep serta menghimpun kenyataan yang ada.

Sumber data yang digunakan di sini adalah sumber data primer dan sekunder. Sumber data tersebut dikumpulkan melalui metode observasi, wawancara dan dokumentasi dan kemudian diolah melalui tiga tahapan dan dianalisis dengan mengunakan metode deskritif kualitatif.

\section{HASIL DAN PEMBAHASAN}

\section{Hasil}

Berdasarkan hasil analisi didapatkan beberapa faktor yang menyebabkan muncul dan berlangtersebut. Adapun be- Begubalan sungnya tradisi ketidak ,Pertama ; berapa faktor tersebut antara lain .betulong gawi adilan dalam pengamalan tradisi 
masa sebelumnya terdapat tradisi-Pada masa namun da- ,gawi betulong yang dikenal dengan dinilai betulong gawi lam pengamalannya tradisi tidak adil dan merugikan pemuda sebagai pelamar, sebab pemuda tersebut diharuskan membantu keluarga perempuan dalam bekerja apa saja dalam rentang waktu yang ditentukan oleh keluarga perempuan tersebut, walaupun pemuda tersebut telah membantunya bekerja belum tentu ia diterimah lamarannya. Dalam bekerja tersebut bukan hanya pemuda yang bersangkutan yang terlibat tetapi juga keluarganya. dinilai merugikan, betulong gawi Walaupun meresahkan dan tidak adil oleh para pemuda yang akan melamar gadis pilihannya. Pada masa betulong gawi masa awal, ketidak adilan tradisiinilah yang membidani lahir dan berlangsungya Sebagai bentuk ketidak sepa- .burgubalan tradisi tersebut, betulong gawi katan terhadap tradisi se- bergubalan maka pemuda menemukan ide bagai jawaban terhadap keresahan, kegelisahan dan ketidak adilan yang dilahirkan dari tradisi betulong gawi

Kedua, ada salah satu pihak keluarga yang tidak setuju terhadap hubungan si gadis dan lajang. Bergubalan lahir juga sebagai bentuk protes terhadap hegemoni orang tua terhadap anak-anaknya dalam hal penentuan jodoh atas nama hak ijbar. Pada hakikatnya kedudukan orang tua dalam masalah penentuan pilihan anak adalah sebagai konsultan bagi anak-anaknya bukan sebagai penentu pilihan. Sebagai konsultan ia tidak bisa berkehendak di atas kehendak yang berkonsultasi.

Ketiga, Rasan Tue (lamaran) terlalu berbelit-belit dan memakan waktu yang lama disamping itu juga dirasa tidak praktis dan tidak pasti bermuara pada pernikahan.

Keempat, tradisi ini merupakan cara yang paling tepat untuk mempermudah menuju ke pernikahan.

Kelima, Bergubalan dianggap cara yang lebih praktis dan pasti bermuara pada pernikahan, sebab ada doktrin adat yang dipegang kuat yaitu pelaku bergubalan harus dinikahkan.

Keenam, masyarakat Desa Pagar Agung terbagi menjadi dua golongan dalam minyikapi tradisi bergubalan. Mayoritas masyarakat menerima bergubalan sebagai adat yang telah lama dikenal di dalam kehidupan mereka sehingga mereka memberikan satu doktrin terhadap pelaku bergubalan yaitu harus dinikahkan. Mereka beranggapan bahwasanya bergubalan tidak bertentangan dengan agama Islam, para tokoh agama setempat juga tidak pernah mempermasalahkan tradisi bergubalan. Dalam pandangan masyarakat, bergubalan dinilai sebagai cara yang lebih praktis, cepat dan mudah dalam menuju jenjang perkawinan, hal ini tentunya berbeda dengan rasan tue yang dalam pandangan mereka dinilai terlalu berbelit-belit dan memakan waktu yang lama. Masyarakat juga menilai bahwasanya bergubalan merupakan satu bukti yang sangat nyata bahwa pelakunya telah sanggup dan mampu untuk hidup berumah tangga, oleh karenanya harus diterima sebagai suatu kenyataan yang benar adanya. Adapun sebagian kecil masyarakat yang kurang sepakat adalah orang tua dari pihak gadis. Mereka memandang tradisi bergubalan sebagai cara yang kurang etis. Pandangan ini, menurut penulis tidak berdiri di atas pijakan yang obyektif tetapi di atas subyektifitas mereka sebagai orang tua dari pihak gadis yang merasa tidak dihormati.

\section{Pembahasan}

Islam adalah agama rahmat bagi seluruh alam yang memuat berbagai aturan hukum, moral, politik dan sebagainya untuk menata kehidupan manusia di muka bumi ini. Berbagai macam aturan tersebut terdapat dalam teks suci baik secara tersurat maupun tersirat. Tata aturan hukum tersebut mencakup semua bidang kehidupan tidak terkecuali peminangan. Namun walau demikian bukan berarti Islam menafikan atau menyalahkan tata aturan dan kebiasaan yang telah ada di tengah-tengah masyarakat terlebih dahulu. Selama tata aturan dan kebiasaan tersebut mengandung mashlahah bagi kehidupan manusia, maka selama itu pula Islam memandangnya sebagai kebaikan.

Dari sini bagaimana sesungguhnya Islam melihat tradisibergubalan sebagai tradisi yang telah lama hidup di tengah-tengah masyarat desa Pagar Agung. Untuk memberikan jawaban terhadap pertanyaan di atas, maka dibutuhkan proyek analisis terhadapnya. Dilihat dari konsep dasar peminangan 
dan perkawinan, makabergubalan dapat dilihat dari beberapa sudut pandang yang lebih komprehensif sehingga tadisi perkawinan dengan tradisi ini bisa difahami oleh berbagai kalangan.

Dilihat dari sudut pandang pengertiannya, maka secara definitif bergubalan bisa dikatakan sebagai bentuk peminangan kepada wanita sebab dari sudut pandang tersebut antara peminangan dan bergubalan terdapat titik akulturasi yaitu sama menginginkan wanita yang dicintai untuk menjadi isterinya dan hal tersebut telah dimintakan pesetujuan kepada wanita yang bersangkutan.

Dilihat dari sudut pandang tatacaranya, maka proses tradisi bergubalan yang di dalamnya terdapat permintaan terhadap gadis untuk menjadi isterinya (peminangan) dilakukan oleh dirinya sendiri dan langsung diutarakan kepada gadis yang dicintainya, sebagaimana yang dilakukan sahabat 'Abdurrahman bin 'Auf. Hal ini diceritakan dalam hadits:

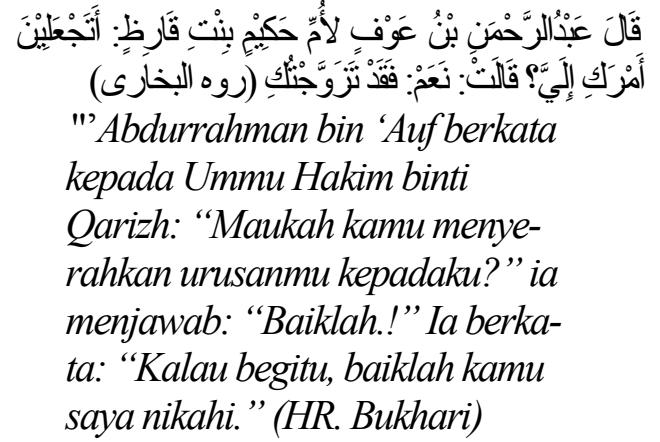

Perbuatan 'Aburrahman bin 'Auf sebagaimana dilukiskan dalam hadits di atas tidak ditegur atau disalahkan oleh Rasulullah saw. Hal ini memberikan signal bahwa tata cara peminangan ala Abdurrahman bin Auf dibenarkan oleh syari'at Islam. Oleh karenanya, orang yang bermaksud meminang boleh datang sendiri kepada perempuan yang bersangkutan.

Akan tetapi problemanya, apa yang dilakukan oleh 'Abdurrahman bin 'Auf tersebut dalam hadits di atas adalah terhadap janda. Sebagian ulama' mengatakan bahwa yang boleh dipinang langsung tanpa melalui wali atau orang tuanya adalah perempuan yang sudah berstatus janda bukan perempuan yang masih perawan.
Pendapat ini tidak mempunyai dasar hadits atau ayat Al-Qur'an, bahkan disebutkan dalam hadits Bukhari dan Muslim yang berbunyi:

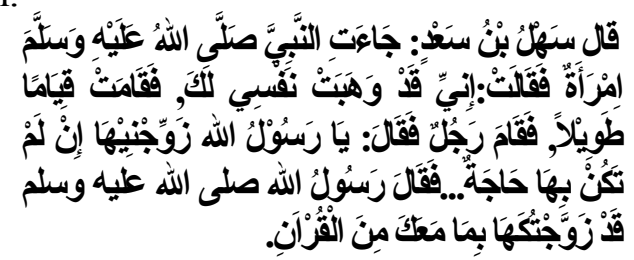
Sahl bin Saad berkata: "Seorang perempuan datang kepada Nabi saw., ia berkata: "Saya serahkan diriku kepada Tuan." Perempuan ini lama berdiri, kemudian ada seseorang laki-laki berdiri, lalu ber- kata (kepada Rasululullah): "Wahai Rasulullah, jika Tuan tidak berminat kepadanya, nikahkanlah dia kepa- daku." Rasulullah saw. Lalu bersabda: 'Aku nikahkan kamu kepa- danya dengan maskawin Al-Qur'an yang telah kamu hafalkan (untuk kamu ajarkan kepadanya)". (HR. Bukhari dan Muslim)

Dalam kasus sebagaimana diceritakan dalam hadits di atas, tidak dijelaskan status apakah perempuan yang dipinang oleh Nabi untuk sahabatnya tersebut janda atau perawan karena dia tidak ditanya oleh Nabi tentang statusnya. Oleh karena itu, kita berpegang kepada yang pokok bahwa perempuan tersebut masih perawan. Pada pokoknya, selama tidak ada keterangan bahwa seorang perempuan telah bersuami atau janda, dia dipandang sebagai perawan. Berdasarkan inilah kita menyatakan bahwa pendapat ulama' hanya janda saja yang boleh dilamar langsung tanpa melalui wali atau orang tuanya adalah tidak benar.

Adapun terhadap bergubalan itu sendiri (pulangnya keduanya kerumah perangkat desa), penulis sendiri menilai itu merupakan strategi agar keduanya segera dinikahkan dan agar hubungan keduanya disetujui, maka dari sini dapat dipahami bahwasanya dalam bergubalan terdapat 
keseriusan dan kesanggupan lajang dan gadis untuk menikah, dalam hal ini Islam memandang bahwasanya jika pemuda telah mampu untuk kawin, maka ia hendaknya melangsungkan perkawinan tersebut karena perkawinan tersebut dapat menjaga pandangan mata dan dapat memelihara kemaluannya.

Berdasarkan deskripsi di atas, maka dalam memandang eksistensi bergubalan tidak cukup dari satu sudut pandang saja. Akan tetapi harus dilihat dari berbagai sudut pandang, baik aspek mashlahah-nya maupun mafsadat-nya, perbadingan mashlahah bergubalan dan mafsadat-nya, penulis berpendapat bahwasanya mashlahah bergubalan lebih besar daripada mafsadat-nya.

Jika dilihat dari konsep dasar adat ('urf) dalam Islam dalam konteks pengertiannya, maka penulis setuju dengan apa yang diinformasikan oleh para informan bahwa bergubalan adalah adat yang telah dikenal ditengahtengah kehidupan mereka dan telah diamalkan oleh para pemuda secara turun temurun. Sesuatu yang telah dikenal oleh banyak orang (memasyarakat) dan telah dikerjakan secara berulang-ulang, maka sesuatu tersebut bisa dikatakan adat sebab memasyarakat dan dikerjakannya sesuatu secara berulang-ulang merupakan syarat untuk terciptanya sebuah adat. Kedua syarat di atas termaktub dalam formulasi definisi adat yang diusung oleh Abdul Wahâb Khalaf yaitu:

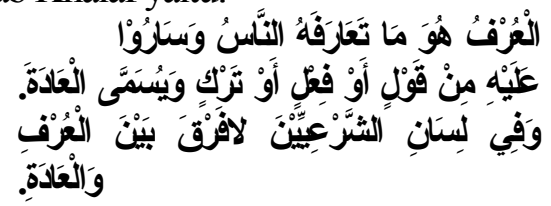

Al-'Urf adalah sesuatu yang telah diketahui oleh orang banyak dan dikerjakan oleh mereka, yang berupa perkataan, perbuatan atau sesuatu yang ditinggalkan. Hal ini dinamakan pulah dengan al- 'âdah. Dalam bahasa ahli syara' tidak ada perbedaan antara al- 'urf dan al- 'âdah."

Dari definisi di atas, maka dapat dipahami bahwasanya syarat-syarat sesuatu untuk dapat dikatakan adat adalah telah dikenal oleh orang banyak atau memasyarakat dan telah dikerjakan oleh mereka. Kedua syarat ini dipenuhi oleh bergubalan yang telah dikenal banyak orang atau memasyarakat menurut Kepala Desa Pagar Agung yang menginformasikan bahwasanya $85 \%$ masyarakat Desa Pagar Agung pernikahannya diawali dengan bergubalan.

Jika dilihat dari sudut pandang macam-macam adat, maka bergubalan bisa dikategorikan masuk pada: (a) dari segi obyeknya bergubalan bisa dikatakan al-urf al'amali (adat yang berupa perbuatan) yaitu kebiasaan masyarakat yang berkaitan dengan perbuatan biasa; (b) dari segi cakupannyabergubalan bisa disebut al-'urf al-khâsh (adat yang khusus) yaitu kebiasaan yang berlaku di daerah dan masyarakat tertentu. Bergubalan masuk dalam jenis ini dengan argumentasi bergubalan hanya terdapat di Desa Pagar Agung dan desadesasekitarnya. bergubalan tidak akan pernah ditemui di daerah lain sehingga tidak bisa di masukkan pada jenis al-'urf al- 'âm (adat yang umum) atau kebiasaan tertentu yang berlaku secara luas diseluruh masyarakat dan diseluruh daerah.

Dari segi keabsahannya, untuk mengidentifikasi apakah bergubalan absah atau tidak, maka penelusuran prosesinya menjadi sangat urgen dan signifikan. Sebab bergubalan tersusun atas beberapa rangkaian perbuatan yang membangun tradisi ini yaitu antara lain; Pertama, perkenalan dan percintaan.Islam tidak memandang perkenalan dan percintaan dua insan sebagai perbuatan yang tercelah. Bahkan dalam Al-Qur'an dijelaskan bahwasanya Allah menciptakan manusia berbangsa-bangsa dan berkabilah-kabilah bertujuan untuk saling mengenal. Islam tidak mematikan fitrah manusia dan instingnya (dzariah), akan tetapi mengatur, menyalurkan dan mengarahkannya ke arah yang positif yang diridhai Allah, dan tidak sampai melanggar batasan-batasan yang 
telah ditentukan oleh Allah.

Kedua, penjemputan mangian, nyusul, pemberian juwada dan pemberian kekendaan. Penjemputan mangian dilakukan oleh pihak kelurga laki-laki-sudah merupakan konsekuensi dari bergubalan begitu juga pemerian juwada yang dilambangkan sebagai permintaan maaf dari pihak kelurga laki-laki atas terjadinya bergubalan itu penulis nilai merupakan tuntutan moral dan etika dalam bermasyarakat atas terjadinya bergubalan tersebut. Adapun pemberian kekendaan kepada keluarga perempuan juga merupakan kebiasaan ketika terjadi bergubalan. Penjempuatan mangian, pemberian juwada dan kekendaan kepada keluarga wanita merupakan sudah merupakan kebiasaan pada saat sesudah terjadi bergubalan. Terhadap kebiasaan-kebiasaan tersebut, penulis menilai tidak ada yang bertentangan dengan syari'at Islam. Justru di dalamnya terdapat nilai-nilai yang dihargai oleh Islam seperti rasa tanggungn jawab yang dibuktikan dengan penjemputan mangian dan nyusul oleh pihak keluarga laki-laki, permohonan maaf yang disimbolkan dengan pemberian juwada dan pemberian restu yang disimbolkan dengan penerimaan kekendaan.

Terhadap kebiasaan-kebiasaan di atas (penjemputan mangian, pemberian juwada dan kekendaan) penulis menilai dapat dijadikan hukum dalam setiap bergubalan sebagaimana dinyatakan dalam qaidah fiqhiyyah.

Berangkat dari uraian di atas, maka penulis berkesimpulan bahwasanya bergubalan ditinjau dari Islam adalah sah, tidak terdapat hal-hal yang menyalahi jiwa syariat Islam.

\section{KESIMPULAN DAN SARAN}

\section{Kesimpulan}

Berdasarkan paparan dan analisis data, maka dapat ditarik beberapa kesimpulan sebagai jawaban atas kajian tradisi bergubalan yang di- angkat yaitu antara lain; pertama, latar belakang berlangsungnya tradisi bergubalan di Desa Pagar Agung, Kecamatan Rambang, Kabupaten Muara Enim Sumatra Selatan adalah tidak terlepas dari beberapa faktor yaitu; (a) Tradisi betulong gawi yang dinilai tidak adil, merugikan dan meresahkan para pemuda yang akan melamar gadis; (b) Adanya satu pihak keluarga yang tidak setuju terhadap hubungan gadis dan bujang; (c) Rasan Tue (lamaran) terlalu berbelit-belit dan memakan waktu yang lama disamping itu juga dirasa tidak praktis dan tidak pasti bermuara pada pernikahan.

Kedua, dalam memandang tradisi bergubalan, masyarakat Desa Pagar Agung Kecamatan Rambang, Kabupaten Muara Enim Sumatra Selatan terbagi pada dua golongan. Satu golongan yang sepakat dan satu golongan yang kurang sepakat.Tetapi mayoritas masyarakat menerima dan sepakat terhadap tradisi bergubalan.

Ketiga, setelah bergubalan dilihat dari berbagai sudut pandang baik dari konsep dasar peminangan (khithbah) dan perkawinan maupun dilihat dari konsep dasar adat ('urf) penulis tidak menemukan hal-hal yang berkonfrontasi dengan Islam, oleh karenanya penulis menilai keberlangungan tradisi bergubalan ditinjau dari Islam adalah boleh (mubah), tidak terdapat hal-hal yang menyalahi Islam.

\section{Saran}

Bagi orang tua hendaknya menyadari bahwa yang akan menjalani baik buruknya kehidupan rumah tangga adalah anak-anaknya, oleh karena itu hendaknya memposisikan dirinya sebagai konsultan dalam pencarian jodoh anak-anaknya bukan sebagai penentu dan pemegang keputusan yang dapat menimbulkan pemberontakan dari anakanaknya. Kepada pemuda Desa Pagar Agung Kecamatan Rambang, Kabupaten Muara Enim Sumatra Selatan selayaknya sebelum bergubalan diharapkan membicarakan terlebih dahulu tentang hubungannya dengan gadis yang dicintai kepada orang tua si gadis dan orang tuanya sendiri agar keduanya mengetahuinya dan ketika bergubalan nanti mereka mengetahui dengan siapa anaknya bergubalan.

Kepada segenap masyarakat Desa Pagar 
Agung Kecamatan Rambang, Kabupaten Muara Enim Sumatra Selatan diharapkan mampu mempertahankan tradisi bergubalan secara khusus dan tradisi-tradisi yang lain secara umum di tengah-tengah arus modernisasi, globalisasi dan

\section{DAFTAR PUSTAKA}

Achmad, Abu dan Cholid Narbuko. 2005. Metodologi Penelitian. Cet. 7; Jakarta: Bumi Aksara.

Ali, Atabik dan Ahmad Zuhdi Muhdhor. 1996. Kamus Kontemporer ArabIndonesia. Yogyakarta: Yayasan Ali Maksum Pondok Pesantren Krapyak.

Al- Shan'ani, Muhamad bin Ismail alAmiri al-Yamni. 1988/1408. Subul al-Salam. Juz III. Cet.I; Beirut: Daar al-Kutub al-Ilmiya.

Bungin, Burhan. 2001. Metodologi Penelitian Sosial; Format-Format Kuantitatif dan Kualitatif. Surabaya: Airlangga Press.

Dahlan, Abd azis. 1999. Ensiklopedi Hukum Islam. Jilid 1 dan 6. Cet.1; Jakarta: PT Ichtiar Baru Van Hoeve.

Departemen Pendidikan Dan Kebudayaan. 1999. Kamus Besar Bahasa Indonesia. Jakarta: Balai Pustaka.

Ghazaly, Abd. Rahman. 2003. Fiqh Munakahat. Jakarta: Prenada Media.

Haroen, Nasrun. 1997. Ushul Fiqh I. Cet.II; Jakarta: PT Logos Wacana Ilmu.

J. Moleong, Lexy. 2002. Metodologi Penelitian Kualitatif. Bandung: Remaja Rosdakarya. teknologi sebagai adat daerah (local customs) yang merupakan ciri khas daerah tersebut dan juga merupakan ciri khas bangsa Indonesia sebagai negara yang kaya akan budaya, tradisi dan adat istiadat

Khalaf, Abdul Wahab. 1978/1398. 'Ilmu Ushûl al-Fiqih. Cet. XII; (tt): AlNashr Wal-Tauzik

Nadzir, M. 2003. Metode Penelitian. Jakarta: Ghalia Indonesia.

Nuruddin, Amiur dan Azhari Akmal Tarigan. 2004. Hukum Perdata Islam di Indonesia; Studi Kritis Perkembangan Hukum Islam dari Fikih, UU No. 1/1974 Sampai KHI. Jakarta: Prenada Media.

Ramulyo,Mohd. Idris. 2004. Hukum Perkawinan Islam; Suatu Analisis Dari Undang-Undang No. 1 Tahun 1974 Dan Kompilasi Hukum Islam. Jakarta: PT Bumi Aksara.

Rusyd, Ibnu. 1990. "Bidayatu'l-Mujtahid", diterjemahkan oleh M.A.Abdurrahman dan A. Haris Abdullah, Tarjamah Bidayatu'lMujtahid. Semarang: tp.

Saifullah (t.t) Buku Panduan Metodologi Penelitian, Hand Out, Fakultas Syari'ah UIN Malang.

Thalib, Muhammad. 2006. 15 Tuntunan Meminang Islam. Yogyakarta: Ma'alimul Usroh.

Ulwan, Abdullah Nasih. 2006. "Adab al-

Khithbah wa az-Zifaf wa Huququ az-

Zaujain", diterjemahkan oleh Abu Ahmad alWakidy, Tata Cara Meminang Dalam Islam. Jakarta: Qathi Press. 